\title{
立体写真測量を用いた風の観測法
}

\section{Development of Wind Observation System Utilizing Stereo Photogrammetry}

\author{
小泉俊雄* \\ Toshio KOIZUMI
}

\begin{abstract}
The objectives of the study are to develop a system to measure the data of wind flow in both the horizontal and vertical directions utilizing stereo photogrammetry, and to establish the methodology for three dimensional measurement on site of wind flow near the ground surface.

This system uses two cigar-shaped kite balloons equipped with a $35 \mathrm{~mm}$ still camera or four $35 \mathrm{~mm}$ still cameras set on the ground, which stereophotograph a third balloon released as a tracer, thereby three-dimensionally analysing the third balloon's path of particle.

As the results of the experimental study on the campus of Chiba Institute of Technology and Kamogawa, Chiba, paths of particles of wind flowing over buildings and mountainous regions were successfully observed.
\end{abstract}

\section{1.はじめに}

現地において地表付近の風の流れの様子を面的な 3 次元で, しかも定量的にとらえることは，風の研究に おいて極めて重要なことである。現地における地表付 近の風の観測は風向風速計を用いて行なわれているの が一般的である。このほか発煙筒を用いて観測すると いった方法なども時に行なわれている。風向風速計で の観測は点における 2 次元観測であり，発煙筒などの 方法は概況を把握するといった事が主なものである。

本研究は風の観測法としての写真測量手法の構築を 目標としたものであり，立体写真測量を用いて水平方 向と鉛直方向の風の流れを測定するシステムを開発し た。この方法は空気と同じ比重にした風船（ノンリフ トバルーン) をトレーサーとして風上より放流し，そ の動きをステレオ撮影し風船の軌跡を 3 次元的に解析 するものである。風船の軌跡は流跡線とよばれるもの であり，風の流れの指標となる。ステレオ撮影にはカ イト気球を用いた空中写真による方法と，地上にてカ

* 千葉工業大学土木工学科

「写真測量とリモートセンシング」Vol. 33, No. 3, 1994
メラを手に持って撮影する地上写真測量による方法を 用いた。

千葉工業大学において行なった建物周辺気流の測定 と，千葉県鴨川で行なった山間部での気流の測定の実 験では, 風の面的な 3 次元観測手法として有効である ことが確認された。

気流の流れの解析は, 通常は流跡線解析で行われ る ${ }^{1)}$ 。本研究に関する既往の研究として, 現地にてノン リフトバルーンや立体写真測量法で気流を観測した代 表的な例として, 相馬の富士山の乱気流の観測がある。 これは1966年 3 月 5 日, 英国海外航空会社 (BOAC) の B-707型機が，富士山風下の御殿場上空において突 然破壊し, 乗客乗員合わせて124名が死亡するという事 故があり，この原因を解明するために行われたもので ある。観測方法は，パラシュートに吊るされたフラッ シュ筒を測量用カメラ（ウイルド P-30）による立体写 真測量法によって撮影し，それから気流を求める方法 と，富士山頂からノンリフトバルーンを飛ばし，それ をトラッキングレーダで追跡して気流を求める方法で ある。ここで使用されたノンリフトバルーンはレー ダー電波の反射効率を高めるためにポリエステル膜の 表面にアルミニウムコーテイングされた直径 $80 \mathrm{~cm}$ の 球形気球であり，トラッキングレーダーは迫撃砲弾を 
索敵するレーダーで, 自衛隊の協力の基で行われた。 フラッシュ筒と立体写真測量法による方法は富士山風 下の広範囲における風を一挙に観測する事が出来, 無 浮力気球の方法は飛しょう経路における気流の細かい 挙動, つまり乱気流を求める事が出来た。この研究は 風洞実験とも合わせて 5 年間にわたり行われ，富士山 風下の乱気流の実体を明らかにした2)。D.H. Pack ら は Los Angeles Basinの水面近くの気流の流れをテト ロン製のノンリフトバルーンを用いて観測した。バ ルーンの位置はレーダーおよびトランスポンダを用 い，平面的に約 100 キロ四方について観測した ${ }^{3)}$ 。太田 正治らは高度 $200 \mathrm{~m}$ から $900 \mathrm{~m}$ を対象に, ハンリフトバ ルーンとしてのスーパープレッシア気球(定容積気球) の性能テストの結果をビニール製のものと比較し, スーパープレッシア気球が拡散研究に有効である事を 述べている4)。

ノンリフトバルーンではないが気球を用いた風の観 測として, 気象庁でのラジオゾンデの観測は一般的で ある。伊藤らはパイロットバルーンよって得られた上 層の風向, 風速の調查結果と, 地上の大気污染常時測 定局の風向, 風速のデーターを基にし, 東京湾沿岸の 海陸風の動態を推定した。パイロットバルーンの位置 は測風経緯度儀 (セオドライト) にて行われた5)。若松 伸司らは地上における風と污染物質濃度の観測局, パ イロットバルーンによる風の観測, 測定機器搭載の航 空機による観測を組み合わせた観測システムを開発 し, 関東地方の光化学スモッグの生成機構を解明する ための研究を行った ${ }^{6)}$ 。西村純はその著書の中で気球 を用いた多くの観測例を述べている7)。

トレーサーガスを放流し気流を調べる方法も多く行 われている。宇田川満らは, 東京湾周辺の污染物質の 移流のメカニズムを解明するために，トレーサーガス (六フッ化イオウ，フロン13B1）を放流し解析した1)。 岡本真一らは, 複雑地形上における煙の拡散に影響を 及ぼす気象条件を把握するために, 栃木地区において， パイロットバルーン，低層ゾンデなどによる気象観測 及びエアートレーサー拡散実験を実施した。この結果 より, 山谷風の発生時などの風速と気温の鉛直分布, 山風中でのトレーサーの拡散幅などを検討した ${ }^{8)}$ 。

石崎健二は， 2 地点より非測定用の $35 \mathrm{~mm}$ カメラを 用いて, 煙突から出た煙の三次元的運動を測定し，そ の有効性を検討するとともに, 煙塊の運動について検 討した。このでの方法は写真測量というょりは写真を
用いた測定の分野に属するものである9”。

この他トレーサー法によって風の流跡線を求める方 法にはいくつかのものがある10),11)

風の流れの場を研究するには現地観測のみでなく, 風洞実験, 数值解析といった方法があるが, 佐藤浩ら はその論文の中で現地において立体的な気流場を観測 する事は実際上の問題として難しく, また, 観測が可 能だとしてもかなり労力を要し時間もかかる。いきお い風洞実験や数值実験で行わざるを得ない状況にあ る。風洞実験は相似律の面, 数值実験は多くの仮定が 入るなど問題が多いと述べている ${ }^{12)}$ 。簡素化された現 地観測システムが必要であることが分かる。

上述のように, 既往の研究として多くのものあるが, これらの研究を概観するに, かなり大がかりな観測で ある事，またラジオゾンデ，パイロットバルーンによ る方法は風を立体的な面で一挙に観測する事は難し く,トレーサーガスによる方法も気流の細かい挙動の 観測は困難である。煙による方法は手軽ではあるが， 煙の濃度が観測精度に大きく影響するほか, 煙が途中 で見えなくなるなど流跡線を描くには問題が多い。本 研究は局所地域の地表付近の風の流跡線観測に限定し て, 写真測量とノンリフトバルーンを用いる事により, 簡単にしかも立体的な面で風を一挙に観測する事が出 来, 気流の細かい挙動も観測できる方法を目指したも のである。

\section{2. 空中写真測量を用いた観測法}

\section{(1)観測システム}

本方法は 35 ミリスティルカメラを搭載した 2 個のカ イト気球を用いて行なうものである。

本システムは図2-1に示すように, 観測地域上空にモ ニター用の V.T.Rカメラと, 撮影用のスティルカメラ を搭載した 2 個の係留気球をある距離離して飛揚させ る。そして, 観測地域の風上から大気と同じ比重にし た風船を放流し，その流れる様子を一定時間ごとに上 空の 2 台のスティルカメラで同時に撮影し, ステレオ 写真として解析するものである。その結果風船の 3 次 元的な流跡線図が得られる。図2-2に撮影から流跡線図 を得るまでのフローを示し, 罒2-3にシステムの装置を 示す。

カイト気球による空中写真撮影装置は, 著者が以前 より測量調査の目的で開発を進めてきたものである 
が13),14)，今回この装置を風の観測用（移動物体のステ レオ撮影) のために次の点を重点に改良を加えた。す なわち, (i) 2 台同時にシャッターが切れること。(ii) カ メラの方向制御のしやすさ，(iii）カメラを搭載してい る空中プラットホームが，強風により撮影に不利な動 きやトラブルが発生しないための強風安定性の向上。

その結果, (i)の同時シャッターについては, 図2-4の 送受信システム図に示すように，シャッター制御用を 別回線として独立させた。すなわち一つの送信機（こ こでは 2 号機操作用の送信機) のシャッター用のレ バーを操作すると，その信号が送信されて双方の受信 機に同時に受信され，シャッター用のサーボが作動し て2 台同時にシャッターが切れるようにした。

タイムラグの減少については，バッテリーのロスを 抑えるために, シャッター専用のバッテリーを付けた。 またシャッター用サーボの回転角度をできるだけ小さ くし，しかも回転速度（作動速度）の速いフタバ社製 S9601型サーボを使用した。これにより，2台のシャッ ターのタイムラグを $1 / 24$ 秒以内にすることができた。

この $1 / 24$ 秒の夕イムラグが測定精度にどの程度影響 をおよぼすかを考察する。風速をカイト気球の飛揚制 限である $6 \mathrm{~m} / \mathrm{s}$ とすると，放流された風船が完全に水 平移動したとして，1/24秒間に風船は水平距離で $25 \mathrm{~cm}$ 移動することになる。解析に用いた六つ切り写真上で の縮尺は約 $1 / 1000$ であるから， $25 \mathrm{~cm}$ の移動距離は写 真上に $0.25 \mathrm{~mm}$ の誤差として現れる。この $0.25 \mathrm{~mm}$ を 写真座標の測定誤差として考えて, 地上写真の水平方 向の位置 $(\mathrm{X}, \mathrm{Y})$ と鉛直方向の位置 $(Z)$ の誤差を次の
式で計算する。

$$
\begin{gathered}
\sigma_{\mathrm{x}}=\sigma_{\mathrm{Y}}=\frac{\mathrm{H}}{\mathrm{f}} \sigma_{\mathrm{P}} \\
\sigma_{\mathrm{Z}}=\frac{\mathrm{H}}{\mathrm{f}} \frac{\mathrm{H}}{\mathrm{B}} \sigma_{\mathrm{P}} \\
\text { ここで } \mathrm{f}: \text { : カラの画面距離 } \\
\mathrm{H}: \text { 撮影距離 } \\
\mathrm{B}: \text { 撮影基線長 } \\
\sigma_{\mathrm{X}}, \sigma_{\mathrm{Y}}: \text { 水平方向の誤差 } \\
\sigma_{\mathrm{Z}}: \text { 鉛直方向の誤差 } \\
\sigma_{\mathrm{p}}: \text { 写真座標の測定誤差 }
\end{gathered}
$$

計算の結果， $\sigma_{\mathrm{x}}=\sigma_{\mathrm{Y}}=\sigma_{\mathrm{z}}=25 \mathrm{~cm}$ となり十分観測に耐 えうるものであることが分かる。

どの位タイムラグがあるかについては次の実験を 行って確認した。すなわち，パソコンのモニター上に 1 〜 1000 までの数字を順次出力するプログラムを作成 し，このモニターの前に気球に搭載するスティルカメ ラを 2 台設置し，製作した同時シャッター制御装置を 用いて36枚連続写真撮影を行なった。その結果，2 台 のカメラで撮影された写真上でのモニターの数字のズ レは, 最大 3 であった。ここでパソコンのモニターが 1 を出力してから 1000 を出力し終わるまでの時間を, ストップウオッチで計測した結果13.8秒であったの で，(13.8/1000) × 3 で計算すると0.0414秒（1/24.15 秒）となる。このことよりシャッターのタイムラグの 最大を $1 / 24$ 秒とした。なお本夕イムラグ計測の実験に あたっては，実際の使用時の電池の消耗を考え，フィ ルム 2 本分 (72枚) のシャッターを切った後の状態の

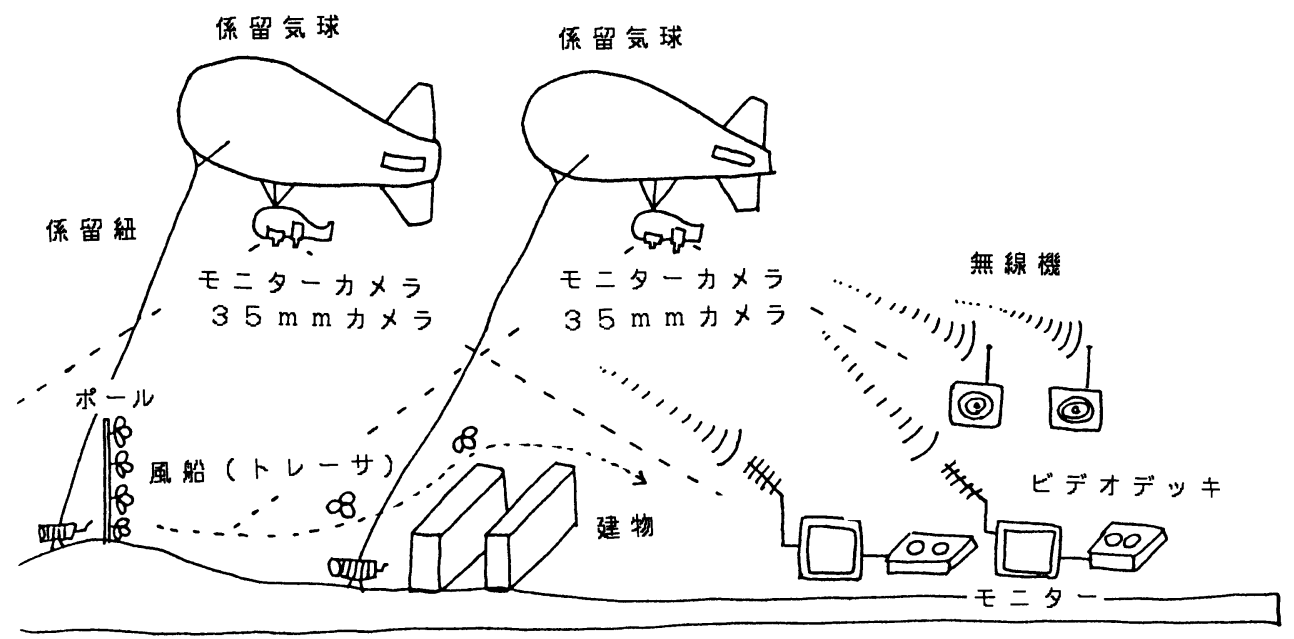

図2-1 空中写真測定法のシステムの概要 


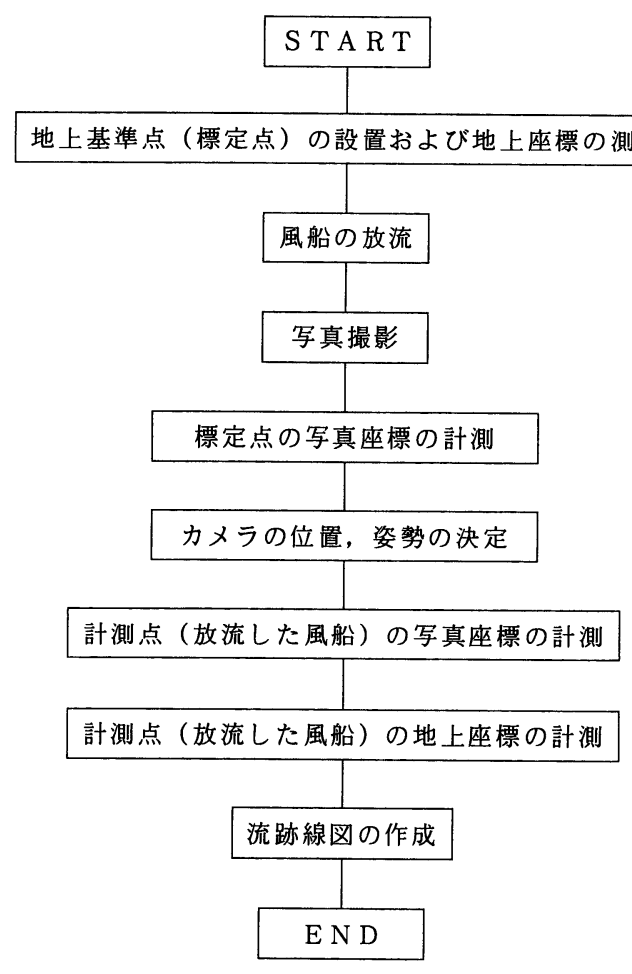

図2-2 写真測量法による流跡線観測のフロー

電池を使用した。

(ii)のカメラの方向制御については，スティルカメ ラと V.T.R カメラの一体化およびカメラの回転制御 範囲の拡大を計り（水平回転 $360^{\circ}$ 以上，鉛直回転 $\pm 90^{\circ}$ 以上), 下半球全域にすばやくカメラを向けることがで きるようにした。

(iii)の強風安定性については，カメラの入っている 空中プラットホームを, 流線型により近いものに変え, また，尾翼をプラットホームの重心からできるだけ離 れた位置に付けるなどの改良を行った。

これらにより気球が風により撮影中に多少移動して も問題なく撮影が可能になった。

撮影·解析装置の仕様を表2-1に示す。なお, 本研究 に用いた気球は地上風速が $8 \mathrm{~m} / \mathrm{s}$ 以上になると安定 性がなくなり，また係留索の破断も予想されるため地 上風速が $0 \mathrm{~m} / \mathrm{s}$ から $5 \sim 6 \mathrm{~m} / \mathrm{s}$ 程度までが適当と考 えられる。

(2)建物周辺気流の流跡線測定への適用

本システムを建物を越える風の流跡線の測定に適用 させた。

\section{表2-1 撮影・解析装置の仕様}

(a) カイト気球

形＼cjkstart状：飛行船形（流線型）

材 質：ポリウレタン

大きさ: $7 \mathrm{~m}^{2}$ (長さ $6.6 \mathrm{~m}$, 最大直径 $1.8 \mathrm{~m}$ ) $4.25 \mathrm{~m}^{3}$ (長さ $5.2 \mathrm{~m}$, 最大直径 $1.5 \mathrm{~m}$ )

ヘリウムガス : $7 \mathrm{~m}^{3}, 4.25 \mathrm{~m}^{3}$

搭載重量: $5.0 \mathrm{~kg}, 3.0 \mathrm{~kg}$

上昇高度： $800 \mathrm{~m}$

支持方式：ひも（2 本支持，ケルビンひも)

(b) スティルカメラ

形 式：35ミリ自動巻き（オリンパス $\mathrm{OM}-1$, キャノン T70)

重 量: $1.5 \mathrm{~kg}(\mathrm{OM}-1), 0.7 \mathrm{~kg}(\mathrm{~T} 70)$

シャッター: 無線操作

2 個のカメラのシャッターのタイムラグ：0.04秒以下

焦点距離：28ミリ

フィルム: カラーフィルム

(c) モニターおよび V.T.R カメラ

V.T.R カメラ：ペンタックス PC-K1200（カラー） 890g

ソニー CCD (白黒)

レミッター：ST $84 \mathrm{U}$

$400 \mathrm{~g}$

送信方式：無線 (UHF)

送信距離 : $1000 \mathrm{~m}$

バッテリー：800mA

八木アンテナ

ブースター

モニターテレビおよび録画装置

(d) 姿勢制御装置

制御方式：セールサーボ 2 個を用いた無線操作

回転範囲：水平角 360 度, 鉛直角 $0 \sim \pm 90$ 度 (水平 10 度, 鉛 直 5 度ずつ制御可能)

制御範囲：約 $1000 \mathrm{~m}$

(e) 解析装置

デジタイザー：分解能 $0.025 \mathrm{~mm}$

パソコン：NEC9801VX

\section{(1)実験}

実験は図2-5に示す千葉工業大学芝園校地において, 建物周辺気流の流跡線の測定を行なった。芝園校地は 約 $520 \mathrm{~m} \times 240 \mathrm{~m}$ の敷地である。校内は平坦であるが, 図2-5の*部分に，高さ $3.5 \mathrm{~m}$ 程の築山がある。

撮影は 2 個の気球を約 $200 \mathrm{~m}$ 離して，4号館と 7 号 館の上空 $200 \mathrm{~m}$ ほどに係留し， 2 号館， 3 号館，5号館， 7 号館，築山を見る形で撮影を行なった。

実験の対象区域は図2-6に示すように 3 号館, 5 号館 および築山を結ぶルートとして行った。

トレーサーとして放流する風船は, 写真判読に必要 な大きさを有すること, 判別に有利な色が数種そろっ ていること, また, 風船の中につめるへリウムガスが 漏れにくい事などの条件が必要である。今回はこれら の条件のうち一個の風船で写真判読に必要な大きさの ものが得られなかったため, やむを得ず直径約 $50 \mathrm{~cm}$ 


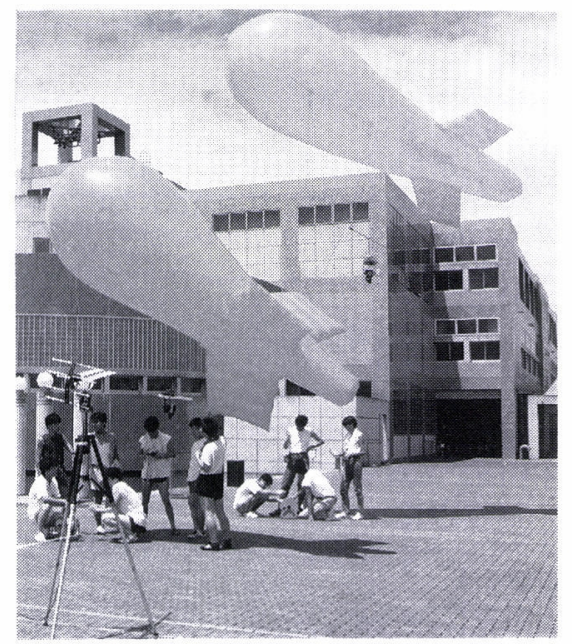

(a) カイト気球

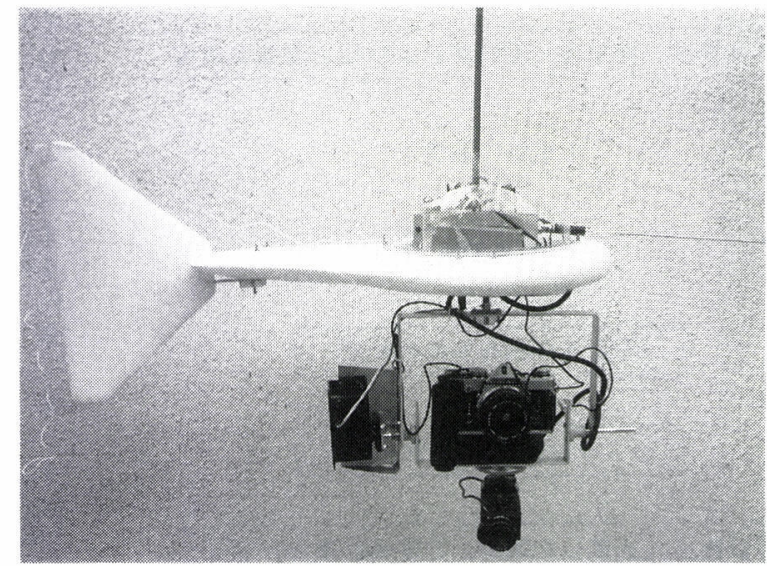

(b) 35 ミリスティルカメラとVTR カメラおよび姿勢制御装 置

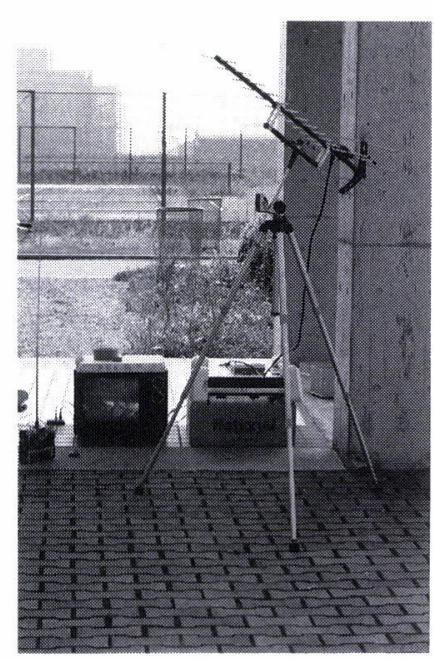

(c) モニターと地上受信システ 厶

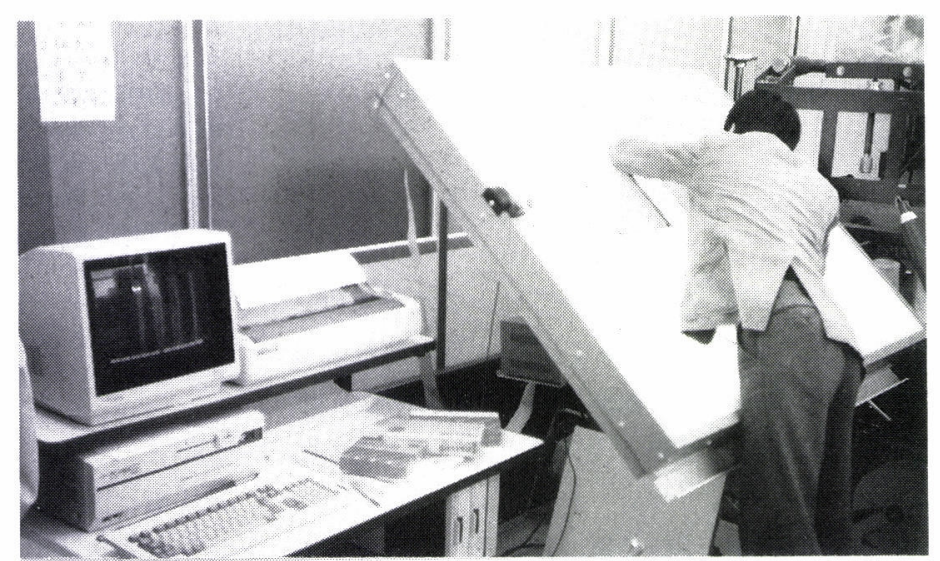

(d) 写真解析装置

図2-3 空中写真撮影・解析システム

のものを 3 個組み合わせて 1 組として使用し， $6 \mathrm{~m}$ の ポールに上から $1 \mathrm{~m}$ おきに 4 組風船を取り付けいっ せいに放流した。通常，浮子による流速観測などでは 複数個投入し，そのばらつき值から流れの場の流速值 等の代表性を評価するが本実験ではそのようなことは せずに，1組ごとの風船を気流の代表值とした。

撮影時の風速は, 図2-5の*印の場所に立てた地上高 $6 \mathrm{~m}$ の鉄塔に風向風速計を設置し測定した。

風船の放流時における風向, 風速を表2-2に示方。第 1 回目の放流は図2-6に示す築山から行い, 第 2 回目の
放流は 2 号館と 3 号館の間の中庭より放流した。第 3 回目は 5 号館屋上よりおこなった。なお第 3 回目は, ポールを用いずに風船を手に持った状態で放流した。 撮影は 1 回目30枚, 2 回目33枚, 3 回目27枚撮影した。 解析は撮影された写真を六切りサイズ $(16.5 \mathrm{~cm} \times$ $24.5 \mathrm{~cm})$ に引き延ばし, デジタイザーとパソコンを用 いて風船の座標を算出した。算出には(社日本写真測量 学会の「一般カメラによる 3 次元座標計測プログラム PGMAN」を用いた。内部標定にあたっては, 主点の 位置のずれおよび画面距離のみの要素を考慮し, レン 


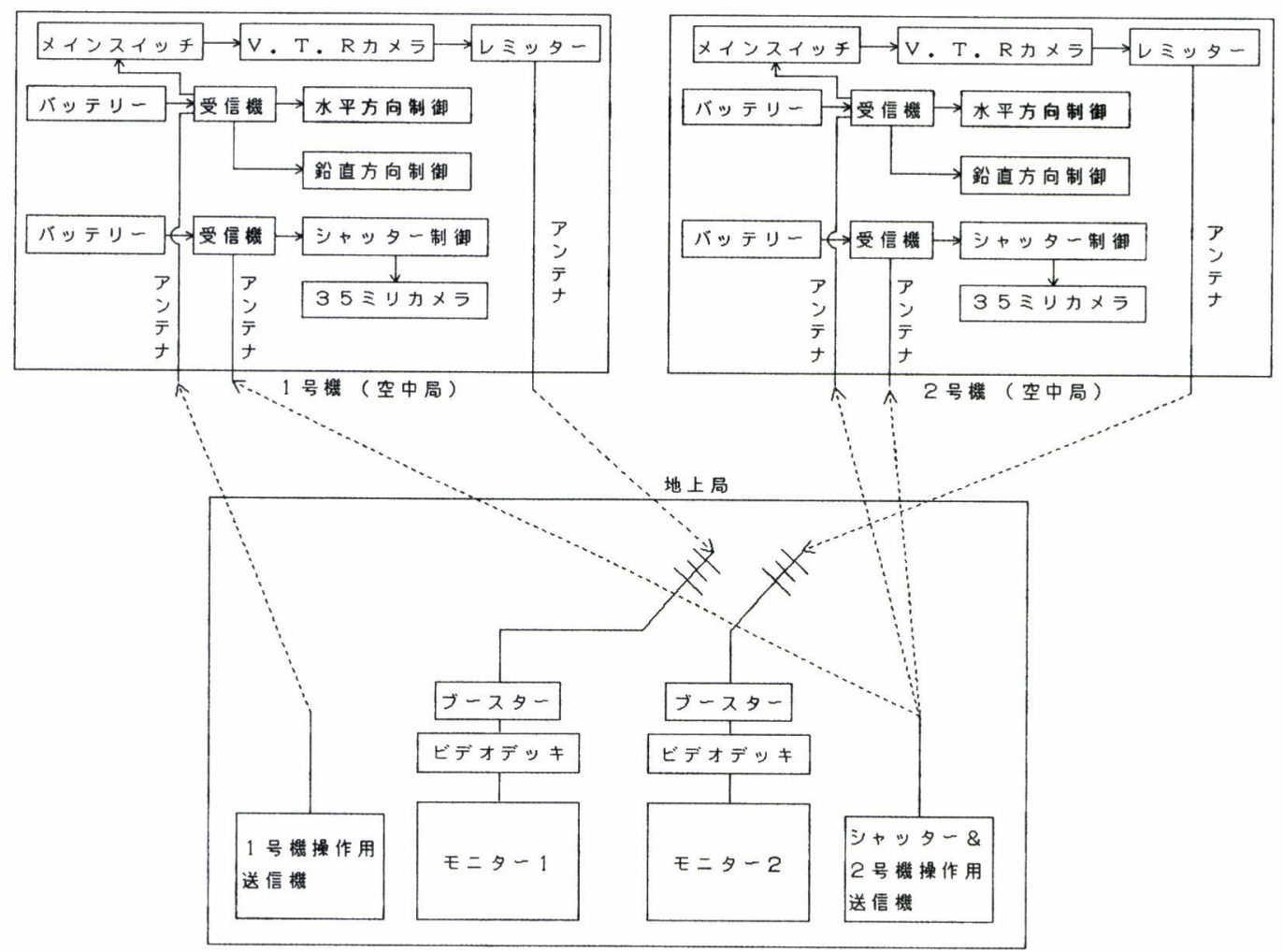

送受信システム図

図2-4 送受信システム図

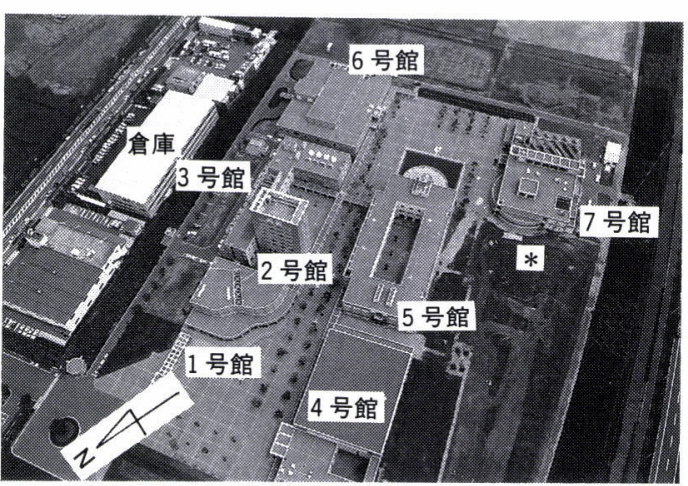

図2-5 実験現場

ズディストーション, フィルム平面度, フィルムの伸 縮, デジ夕イザーの歪, 大気屈折の補正は行わなかっ た。用いられた基本式は以下のとおりである ${ }^{15), 16) 。 ~}$ $x=-f \frac{a_{11}\left(X-X_{0}\right)+a_{12}\left(Y-Y_{0}\right)+a_{13}\left(Z-Z_{0}\right)}{a_{31}\left(X-X_{0}\right)+a_{32}\left(Y-Y_{0}\right)+a_{33}\left(Z-Z_{0}\right)}+x_{p}$ $y=-f \frac{a_{21}\left(X-X_{0}\right)+a_{22}\left(Y-Y_{0}\right)+a_{23}\left(Z-Z_{0}\right)}{a_{31}\left(X-X_{0}\right)+a_{32}\left(Y-Y_{0}\right)+a_{33}\left(Z-Z_{0}\right)}+y_{p}$
ここで $\left(x_{p}, y_{p}\right)$ : 写真中心と主点のずれ

f : 画面距離

$(x, y)$ : 写真中心を原点とする指標座標

$\left(\mathrm{X}_{0}, \mathrm{Y}_{0}, \mathrm{Z}_{0}\right)$ : 投影中心

$(X, Y, Z)$ : 対称物の地上座標

$\left\{a_{i j}\right\}$ : 回転行列

$\left(\begin{array}{lll}\mathrm{a}_{11} & \mathrm{a}_{12} & \mathrm{a}_{13} \\ \mathrm{a}_{21} & \mathrm{a}_{22} & \mathrm{a}_{23} \\ \mathrm{a}_{31} & \mathrm{a}_{32} & \mathrm{a}_{33}\end{array}\right)=\left(\begin{array}{ccc}1 & 0 & 0 \\ 0 & \cos \omega & -\sin \omega \\ 0 & \sin \omega & \cos \omega\end{array}\right)$
$\left(\begin{array}{ccc}\cos \varphi & 0 & \sin \varphi \\ 0 & 1 & 0 \\ -\sin \varphi & 0 & \cos \varphi\end{array}\right)\left(\begin{array}{ccc}\cos \mathcal{c} & -\sin \mathcal{1} & 0 \\ \sin \mathcal{c o s} \mathcal{c} & 0 \\ 0 & 0 & 1\end{array}\right)$

๗：X軸まわりの回転

$\varphi: \mathrm{Y}$ 軸まわりの回転

$\varkappa: Z$ 軸まわりの回転

上式において未知変量は $\left(\mathrm{X}_{0}, \mathrm{Y}_{0}, \mathrm{Z}_{0}\right),(\omega, \varphi, \varkappa) の 6$ つの外部標定要素のほかに, $\left(x_{p}, y_{p}, f\right) の 3$ つの内部標 


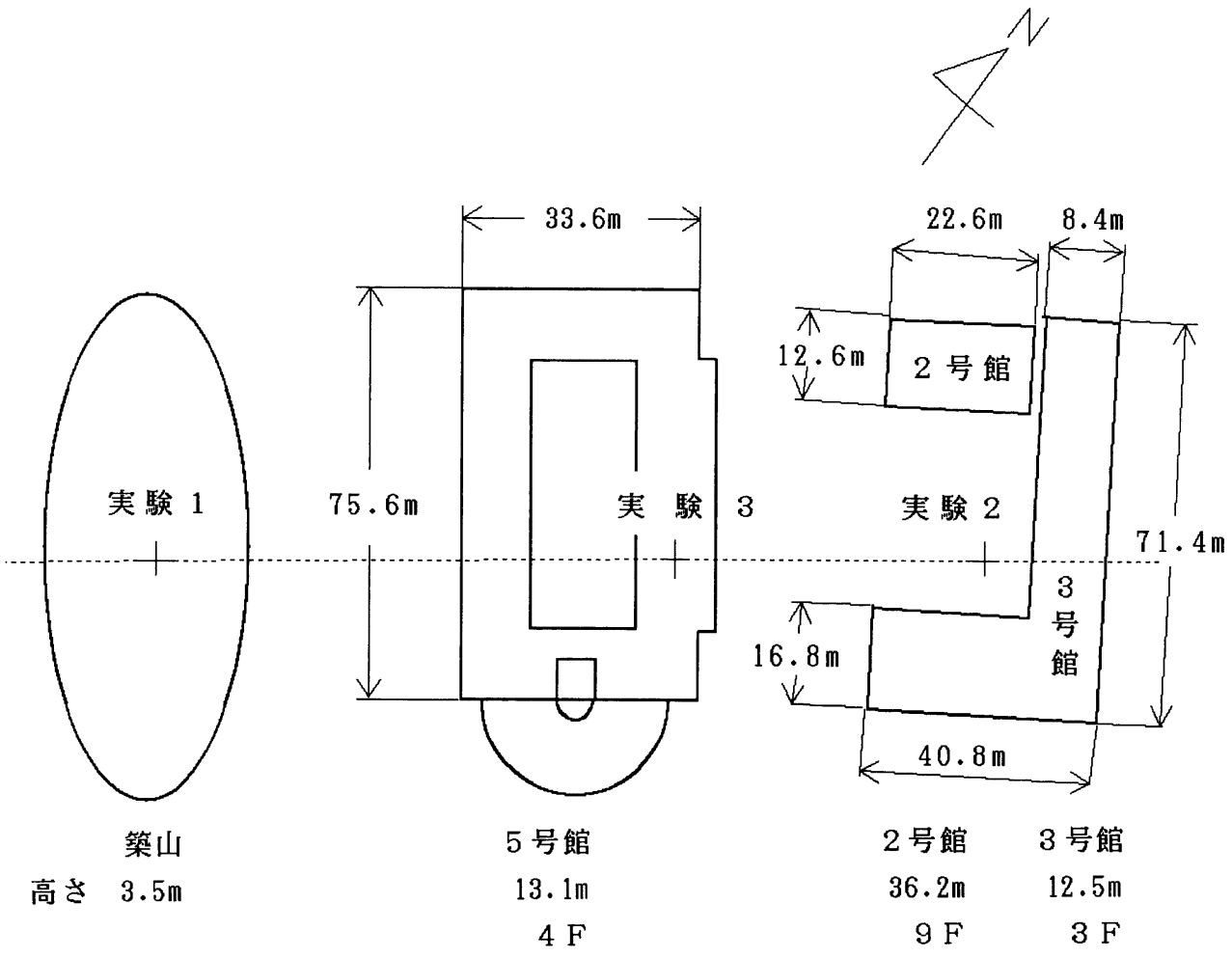

図2-6＼cjkstart風船の放流ルート

表2-2 撮影時の風向, 風速

\begin{tabular}{c|c|c}
\hline 実 験 & 風 向 & 風 速 $(\mathrm{m} / \mathrm{s})$ \\
\hline 1 & $\mathrm{SW}$ & 2.1 \\
\hline 2 & $\mathrm{ENE}$ & 3.7 \\
\hline 3 & $\mathrm{NNE}(10$ 分前 $)$ & $3.3(10$ 分前 $)$ \\
\hline
\end{tabular}

定要素である。

なお，風船の座標測定精度がどの程度であるかの目 安とするために，地上に設置した座標値が既知の対空 標識（基準点）を写真上より計測し比較した。その結 果を表2-3に示す。これによると写真上より計測した座 標値と既知の座標値（地上測量によって定めらた座標 值）との差，すなわち誤差は水平方向で $\pm 18.5 \mathrm{~cm}$ ，鉛 直方向で $\pm 24.34 \mathrm{~cm}$ となった。この程度の誤差は本研 究においては問題ないと考えられる。

(2)実験結果

(1)実験 1 について

解析の結果得られた風船の流跡線図を図2-7に示す。 これは 1 秒毎に撮影し解析したものである。図2-7の(a)
困は鉛直方向移動経路図であり，縦軸を高さ，横軸を 水平距離としている。(b)図は水平方向移動経路図で $\mathrm{X}, \mathrm{Y}$ 座標を表したものである。これらの図は両軸の縮 尺が異っているので注意されたい。

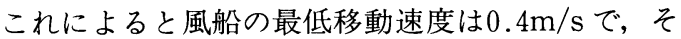
の位置は校舎の手前地上高 $5.5 \mathrm{~m}$ のところである。最 高速度は $6.5 \mathrm{~m} / \mathrm{s}$ で，その位置は校舎 ( 5 号館) の風上 側軒の上 $3 \mathrm{~m}$ ，地上高 $16.5 \mathrm{~m}$ のところであることが分 かる。

(2)実験 2 について

解析結果を図2-8に示す。放流地点は風向に対して高 さ $12.5 \mathrm{~m}$ の 3 号館の背面にあたる。放流時の風は東北 東の風 $3.7 \mathrm{~m} / \mathrm{s}$ である。放流された風船のうち, 地上付 近より放流されたものは地上付近によどんでしまう。 地上高さ $3 \mathrm{~m}$ より放流された $\triangle$ 印の風船は, 放流後す ぐに上昇するが，5号館手前で下降した後，再び上昇 し 5 号館を越えて，その後は水平に流れる。 5 号館の 風上側軒の上では $\triangle \mathrm{N}$ の間隔が大きくなっており，か つ盛り上がりを示している。このことは軒部の剝離流 によるものと考之られる。口印の風船は鉛直方向の動 
表2-3 写真の解析精度

$[\mathrm{cm}]$

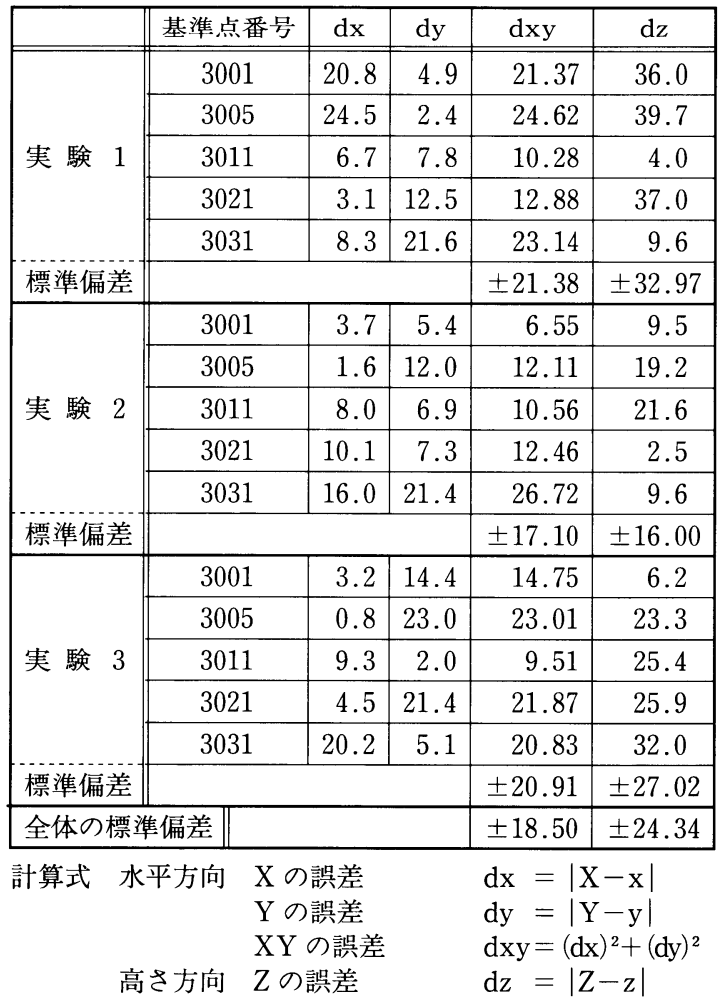

水平方向の誤差の標準偏差 $= \pm \sqrt{\frac{\sum(\mathrm{dxy})^{2}}{\mathrm{~N}-1}}$

鉛直方向の誤差の標準偏差 $= \pm \sqrt{\frac{\sum(\mathrm{dz})^{2}}{\mathrm{~N}-1}}$

$\mathrm{X}, \mathrm{Y}, \mathrm{Z}$ ：地上測量值

$\mathrm{x}, \mathrm{y}, \mathrm{z}:$ 写真より測定した值

$\mathrm{N}$ : 基準点の数

きはほぼ $\triangle$ 印の風船と同じであるが, 図2-8(b)によると 5 号館手前で $\triangle$ 印の風船とは違った方向へそれ，その 後上昇し 5 号館の上を抜ける。地上高 $4 \mathrm{~m}$ より放流さ れた十印の風船は 5 号館手前で下降することなく建物 を越えるが，大きな振幅を持つ状態で建物を越えてい る。なお，図中の流跡線図に於て，線で結んでいない ところは, 風船の判読が不可能であったところである。 (3)実験 3 について

解析結果を図2-9に示す。このときの風は北の風 4 $\mathrm{m} / \mathrm{s}$ 程度と推定される。この図より放流後 5 号館中庭 に流下した $\Delta$ 印の風船が再び上昇し, 建物を出たとこ ろで今度は勢いよく上昇しているのが目立つ。しかし ながら，他の風船は大きく波を打つ格好で 5 号館上空 をぬける。৩印の風船は 5 号館の風下直後でいったん 下降し地表に沿って流れる。

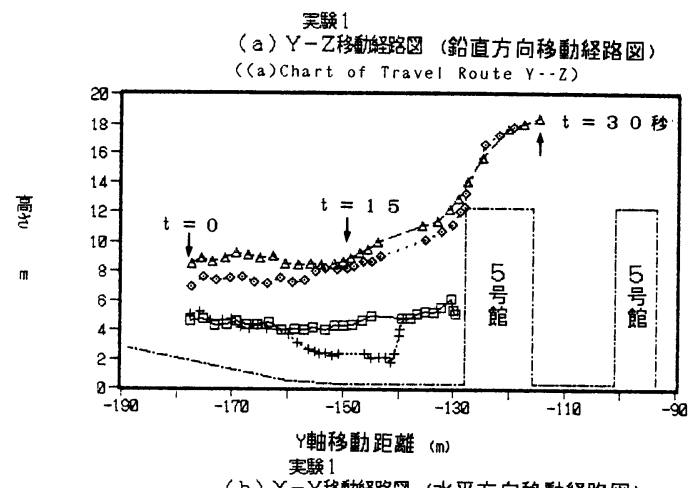

(b) $X-Y$ 移螦経路园（水平方向移動経路图）

((b)Chart of Travel Route $X--Y$ )

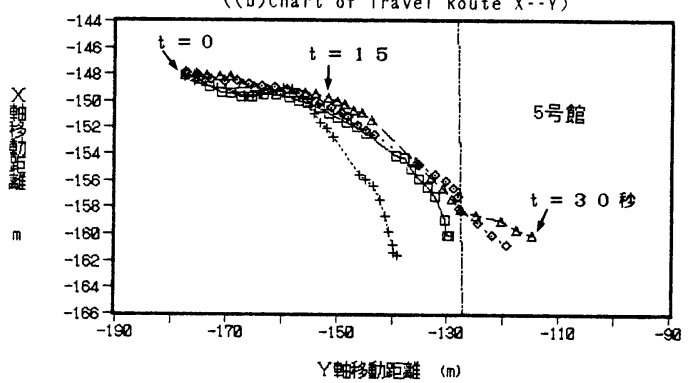

図2-7＼cjkstart流跡線図（実験 1）

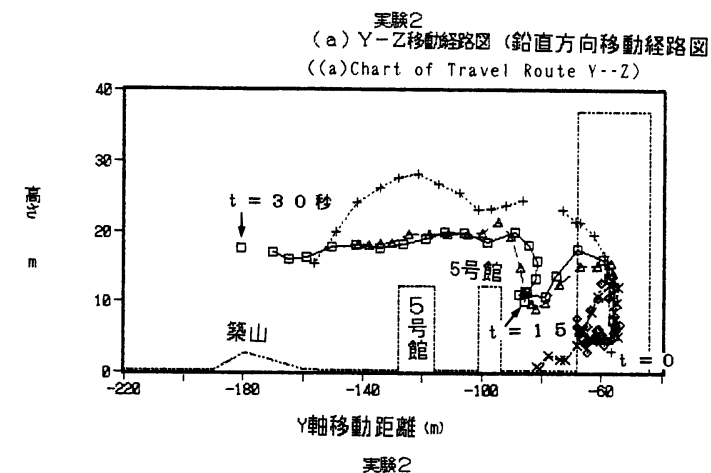

(b) X-Y移新等路図(水平方向移動経路图)

((b)Chart of Travel Route $X--Y$ )

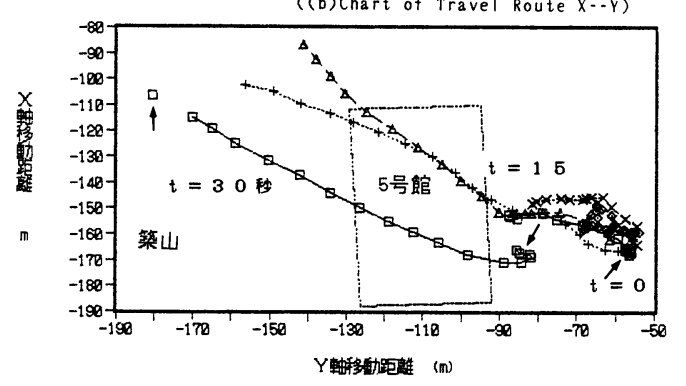

図2-8 流跡線図（実験 2） 

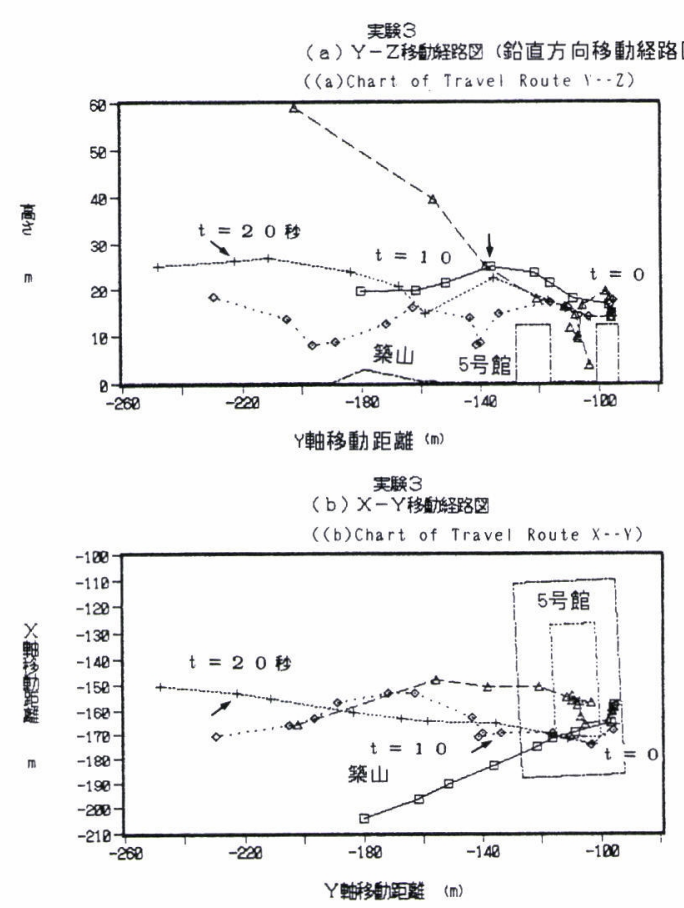

図2-9 流跡線図（実験 3）

\section{3. 地上写真測量を用いた観測法}

(1)観測システム

本方法は地上にてカメラを手に持って撮影する方法 である。本システムは図3-1に示すように, 観測地域周 辺の地上に 4 台のスティルカメラをある距離離して設 置する。これらをインターバロメーターにつなぎ, 一 定時間ごとに同時シャッターが切れるようにする。観 測地域の風上から空気と同じ比重の風船を放流し, そ の流れる様子を一定時間ごとに 4 台のスティルカメラ で追跡し同時に撮影する。撮影された写真をステレオ 写真として解析し風船の 3 次元座標を求めるものであ

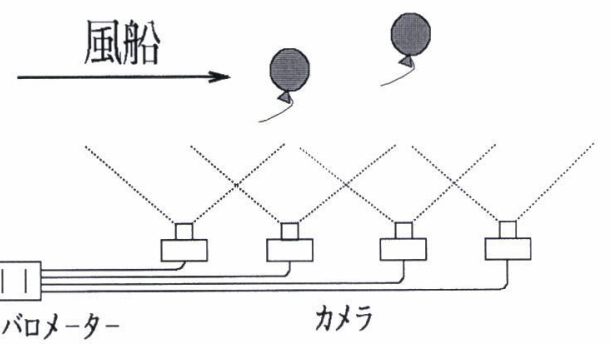

図3-1 地上写真測定法のシステムの概要 $-12-$ (a) 写真撮影器材

\section{表3-1 撮影・解析装置の仕様}

カメラ：35ミリ一眼レフカメラ・モータードライブ内蔵 型 ニコン F-801

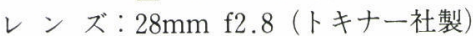

シャッター：インターバロメーター使用によるレリーズでの 作動

フィルム : Fujicolor Super G ASA100

(b) インターバロメーター

形＼cjkstart式：ニコン MT-2

遠隔操作：リモートコントロールコードとスイッチにより 離れた所から電源の $\mathrm{ON} / \mathrm{OFF}$ が可能

(c) デジタイザー

形式：SUMMAGRID（武藤工業株式会社製）

分 解 能: $0.025 \mathrm{~mm}$

(d) コンピュータ：NEC PC9801VX

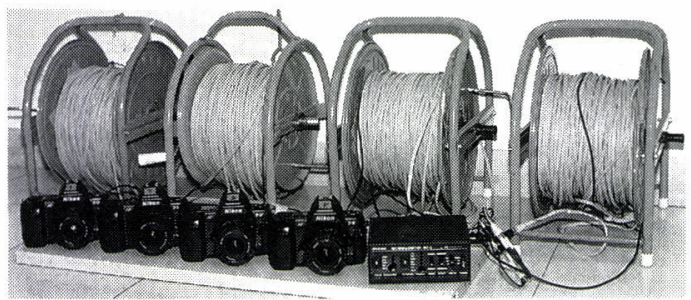

図3-2 使用したカメラとインターバロメーター

る。ここで，4台のカメラを用いたのは，風船の流れ をより広い範囲でステレオ写真撮影を行うためであ る。撮影器材の仕様を表3-1に示し, 使用したカメラと インターバロメー夕を図3-2に示す。

(2)山間部での気流の流跡線測定への適用

(1)実験

1990年12月，千葉県鴨川市に竜卷が発生し多くの被 害が生じた。この竜巻の発生地点は, 眓3-3に示す鴨川 と和田町の境の山間部である。竜巻のルートは地形に 影響されて谷間を通過した。実験は竜巻のルートを知 るための資料収集の一環としても行われた。実験を 行った地域は東西に延びる谷と北西に延びる谷の交差 しているところで, 特に東西方向の谷は西側に標高129 $\mathrm{m}$ の峠があり, 風の流れに地形が大きく影響する場所 と推定される。撮影は図3-4に示すように観測地域周辺 の地上に，三脚を使用せずに手に持った 4 台の $35 \mathrm{~mm}$ 小型スティルカメラをある距離離して配置し風上から 放流した風船を追跡し同時に撮影した。撮影間隔は風 船放流後 8 秒おきとした。

標定点については, 観測地域が広範井にわたるため, 観測地付近の電柱などを標定点として利用した。しか しそれだけでは標定点が偏ってしまうため測量用の 


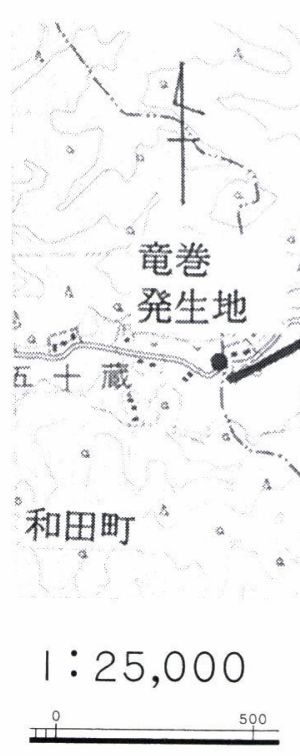

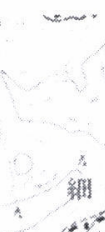
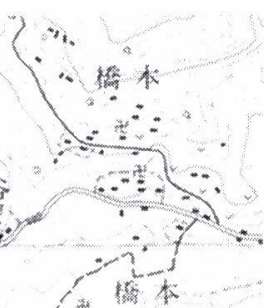

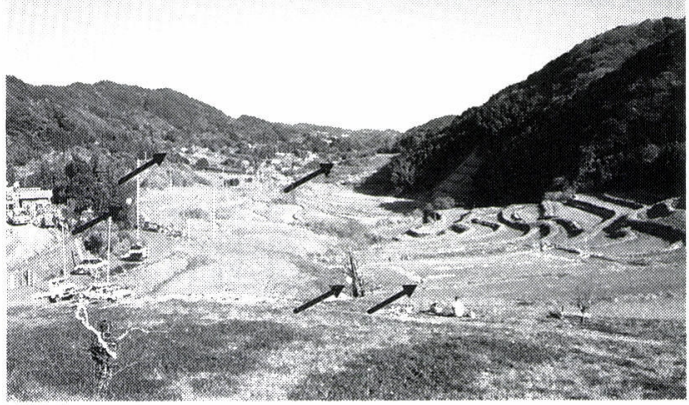

図3-5 解析に用いた写真

撮影地点：カメラ 3

（注）矢印は解析に用いた風船の位置を示すだけのもの 右端の 4 個重なっている風船は解析対象外

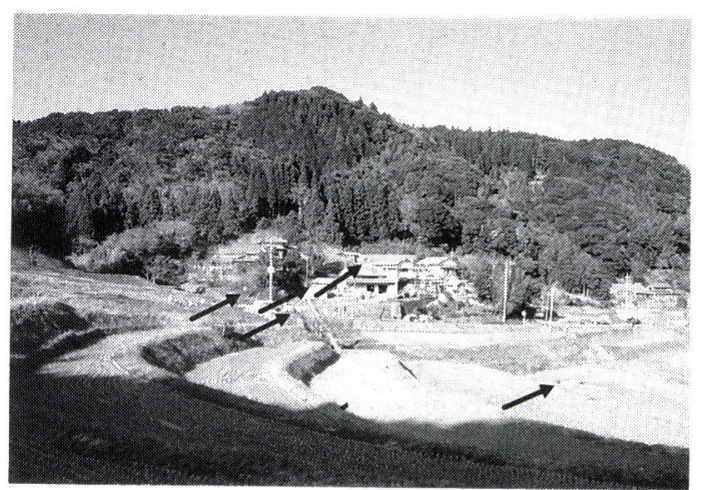

図3-6 解析に用いた写真 撮影地点：カメラ 4

（注）矢印は解析に用いた風船の位置を示すだけのもの 右端の 4 個重なっている風船は解析対象外

の色は赤，青，ピンク，緑，オレンジの5種類である。 風船は手に持っていっせいに放流した。解析は撮影し た写真をサービス版 $(11.9 \mathrm{~cm} \times 8.3 \mathrm{~cm})$ に引き伸ばし， デジタイザーとパソコンを用いて風船の座標を算出し た。使用した写真は放流後 32 秒後, 1 分 12 秒後, 1 分 52 秒後, 2 分 32 秒後, 3 分 12 秒後のものである。図 $3-5$, 図3-6に風船放流32秒後の解析に用いた写真を示す。

(2)実験結果

解析の結果得られた風船の流跡線に関して困3-7に 水平方向移動経路図 $(\mathrm{X}-\mathrm{Y}$ 面) を, 図3-8に鉛直方向移 動経路図 $(X-Z$ 面) を, 図3-9に鉛直方向移動経路図( $\mathrm{Y}$ -Z 面）を示す。図3-3の流跡線図は図3-7の結果を地形 罒にプロットしたものである。これによると放流され た風船が西南西の風にのって谷筋に沿って流れている
ポールを用いて新たに標定点を設置した。トレーサー としての風船はすべて直径 $40 \mathrm{~cm}$ の球形である。風船 
ことがわかる。このルートは竜巻の通過ルートとほぼ 一致するルートである。

\section{凡例}

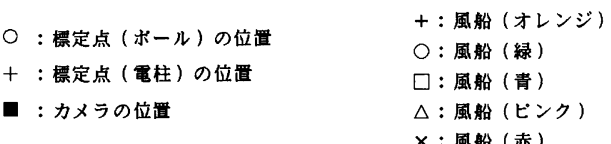

単位: $m$

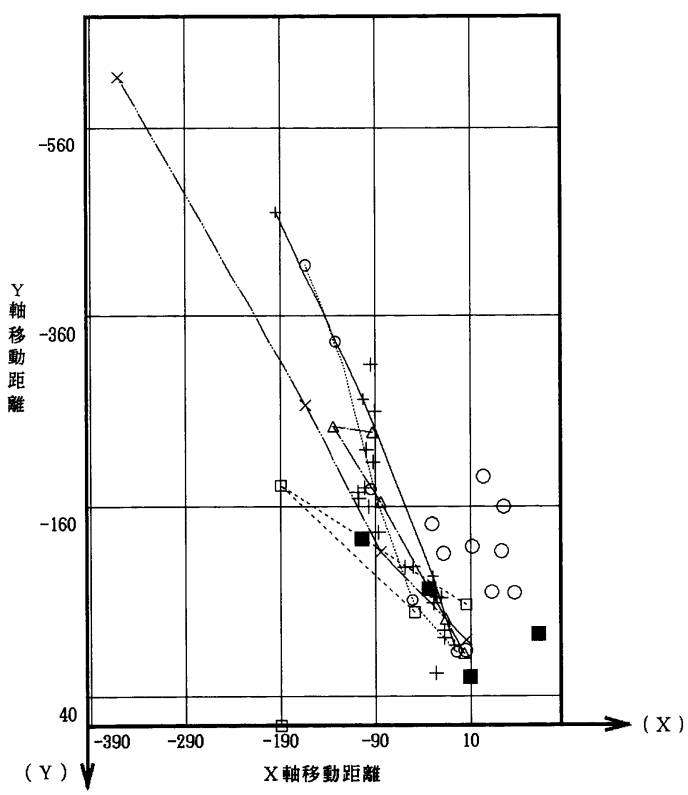

図3-7 流跡線図（水平方向移動経路図, $\mathrm{X}-\mathrm{Y}$ 面）

\section{4. 風船の追随性について}

本論文では空気と同じ比重の風船（ノンリフトバ ルーン）をトレーサーとして放流し気流の流れを測定 したが，この風船がどの程度気流の動きに追随してい るかの問題がある。桑名は高層風観測気球の追随性に ついて流体力学の理論の面より検討している ${ }^{17)}$ 。ここ で述べられている内容が地表風にそのまま適用される とは言い難いが，高層風のみに適応されるだけの内容 ではなく，地表風にも適応可能と考えられるので, こ の論文を基に検討してみる。

風船の運動方程式を立てる際の仮定として, 風船の 形状は球とし，懸垂物についてはその質量だけを考慮 する。気球に対する空気の抵抗は, 気球の空気に対す る相対速度の自乗に比例する。気球は一定の風速 $\mathrm{v}_{0}$ の 気流に流されるとする。

運動方程式を(1)式のように立てる。

$$
\mathrm{M}^{\prime} \frac{\mathrm{dv}}{\mathrm{dt}}=\mathrm{k}\left(\mathrm{v}_{0}-\mathrm{v}\right)^{2}
$$

ただし $\quad \mathrm{v}_{0}>\mathrm{v}>0$

ここで

$\mathrm{M}^{\prime}$ : 風船系の仮想質量

$\mathrm{v}$ : 風船の速度

$t$ : 時間

$\mathrm{k}$ : 速度 $\mathrm{v}$ の風船の受ける空気抵抗と風速との関係 式の比例常数。

$\mathrm{v}_{0}$ : 風速

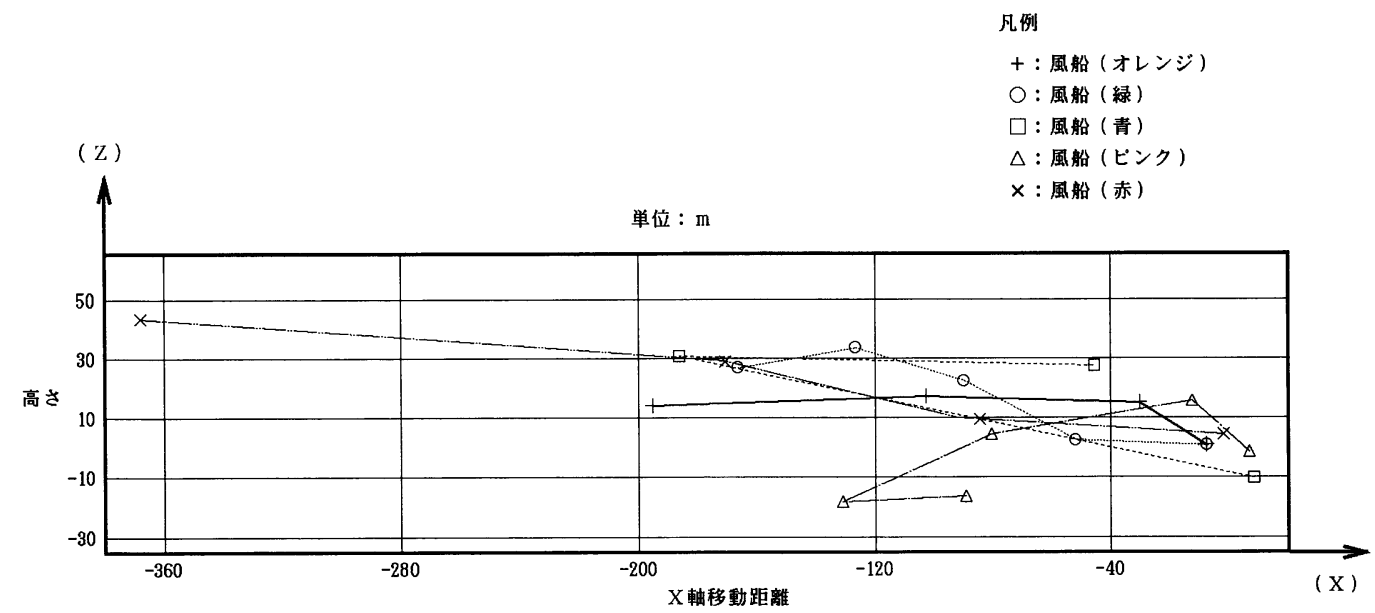

図3-8 流跡線図（鉛直方向移動経路図， X-Z 面） 


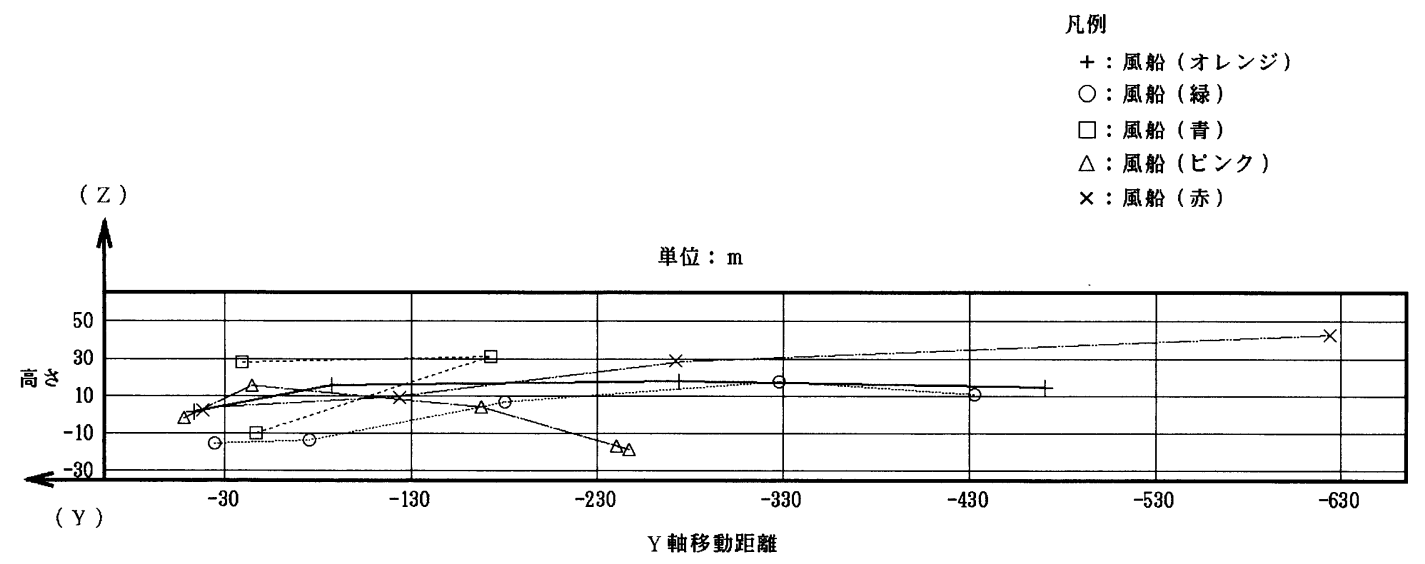

図3-9 流跡線図（鉛直方向移動経路図, Y-Z 面）

この運動方程式を $\mathrm{t}=0$ で $\mathrm{v}=0$ として解くと(2)式に なる。

$$
\mathrm{v}=\mathrm{v}_{0}-\frac{1}{\frac{1}{\mathrm{v}_{0}}+\frac{\mathrm{k}}{\mathrm{M}^{\prime}} \mathrm{t}}
$$

次に風船を一定の風速 $\mathrm{v}_{0}$ の気流中に放した場合の 風船の速度について風船の追随の遅れ時間（追随性） を求めるため $\mathrm{v}=\mathrm{nv}_{0}($ ただし $1>\mathrm{n}>0)$ になる時間を 片とすれば(2)式により

$$
\mathrm{nv}_{0}=\mathrm{v}_{0}-\frac{1}{\frac{1}{\mathrm{v}_{0}}+\frac{\mathrm{k}}{\mathrm{M}^{\prime}} \tau_{\mathrm{n}}}
$$

これより $\tau_{\mathrm{n}}$ を求めると(3)式となる。

$$
\tau_{\mathrm{n}}=\frac{\mathrm{n}}{1-\mathrm{n}} \frac{\mathrm{M}^{\prime}}{\mathrm{kv}_{0}}
$$

て

ここで $\mathrm{n}=0.5$ とした $\tau_{05}$ を求めると(4)式となる。

$$
\tau_{05}=\frac{\mathrm{M}^{\prime}}{\mathrm{kv}_{0}}
$$

(4)式をもとに本論文において風速に対して 5 割に追 随するまでの時間を，第 2 章のビル風の実験および第 3 章の山間部での実験で概算するとそれぞれ 1.3 秒, 0.3 秒となる。

(3)式，(4)式から分かるように，遅れ時間は風船が小 さいほど，また風速が大きいほど小さくなる。

風船やその他のトレーサーに関しての追随性につい ては，このほかいくつかの論文の中にも触れられてい るが理論的，実験的に検討したものは少ない。それら

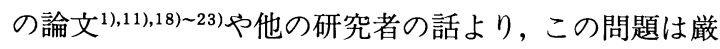

密に考えた場合には多くの問題があり，未だ十分には 解決されていないのが現状である。しかしながら卜 レーサー法は広く一般的に使用されており有効な方法 である。この方法により今まで分からなかった事が分 かるようになる。追随性については更なる研究が必要 である。

\section{5. 結 論}

本研究の結果次の結論を得た。

(1)本方法は現地において気流の流跡線を従来のものに 比べ簡単に，しかも立体的な面で一挙に細かい挙動ま で観測できることが実験により確かめられた。風船の 追随性に関しては十分に解明できなかったが，今まで 困難であった流跡線測定を簡素化した意義は大きいと 考える。

(2)定性的観測とともに，定量的に観測できる方法とし て有効であることが明らかになった。

(3)空中写真による方法は視野が広く，広い範囲の観測 に有効である。地上写真による方法は視野は狭くなる が，手軽で装置や費用も少なく，気球による空中写真 撮影の困難な足場の悪い場所や強風時での観測には有 効である。空中写真測量と地上写真測量の双方の特徵 を生かしての風の観測システムが構築された。

(4)ビル風や山間部での風の観測といった小地域での観 測に有効であることが明らかになった。

(5)観測精度についても十分な結果が得られた。

(6)今後の課題として(1)カイト気球を用いる方法は, 風 速 $6 \mathrm{~m} / \mathrm{s}$ 以下という制限がある。これは風の観測シス 
テムとして大きな問題点である。強風時には凩を用い る等の方法が必要であろう。また，ステレオ写真によ る方法はトレーサーの追跡の容易さに問題点もある。 単写真を用いての方法の開発も必要である。(2)風船の 追随性については放流後 1 秒たらずで風速の約 5 割に 達する事が推定されたが，この問題は今後更なる検討 が必要である。

\section{6. 謝辞}

本研究は千葉工業大学建築学科の羽倉弘人教授, 同 土木工学科の足立一郎教授の多大な御協力のもとで 行ったものであり，ここに心より厚く御礼申し上げま す。

相馬清二氏には富士山風下の乱気流の研究に関し, また桑名十郎氏には風船の追随性について論文の提供 と有益な御教示をいただきました。ここに心から感謝 の意を表します。

(受付1993.11.26, 受理1994.5.20)

\section{参 考 文 献}

1) 宇田川 満ほか：東京湾周辺における気流・污染物質 調查一トレーサ一実験一, 東京都公害研究所年報, 1985 年.

2 ）相馬清二：富士山風下における乱気流の研究, 科学技 術庁特別研究促進調整費並びに気象研究所特別研究費に よる研究, 1988年.

3 ) D.H. Pack and J.K. Angell : Preliminary Study of Air Trajectories in the Los Angeles Basin as Derived from Tetroon Flights, Monthly Weather Review, 1963.

4) 太田正治ほか：スーパープレッシア気球の拡散研究へ の応用, 天気, 16(1), 1969年.
5 ）伊藤政志ほか：東京湾周辺における気流・污染物質調 査一風の立体構造一, 東京都公害研究所年報, 1985年.

6 ）若松伸司ほか：航空機を用いた污染気塊のラグラン ジュ的観測, 国立公害研究所研究報告, 第61号, 1984年.

7 ) 西村純：気球をとばす, 岩波書占, 1975年.

8 ) 岡本真一ほか：複雑地形上におけるエアトレーサ一拡 散実験と山谷風の観測, 天気, 31.5, 1984年.

9 ）石崎健二：煙突から出た煙の三次元的運動の二点写真 法による観測，天気，30.12，1983年.

10）坂上治郎：流れの可視化法, 気象研究ノート, 第 124 号, 1975年.

11）流れの可視化学会：新版流れの可視化ハンドブック， 朝倉書店，1986年.

12）佐藤浩ほか：富士山周辺の流れの風洞実験, 気象研究 ノ一ト，No.118，1974年.

13）村井俊治, 奥田勉, 小泉俊雄, 榎本歳勝：力イト気球 を用いた空中写真測量とリモートセンシング，写真測量 とリモートセンシング, Vol.21，No.2，1982年。

14）小泉俊雄, 村井俊治, 小池俊雄, 真鍋弘道：カイト気 球を用いた空中写真撮影システムとその応用, 写真測量 とリモートセンシング, Vol.25, No.2，1986年.

15）村井俊治ほか：非測定用カメラを用いた解析的写真測 量に関する研究, 東京大学生産技術研究所報告, Vol.129, No.6 (No.191)，1982年.

16) (社)日本写真測量学会 : 解析写真測量 (改訂版), 1989年.

17）桑名十郎：高層風観測気球の追従性について，技術時 報 No.57，札幌管区気象台，1967年.

18）伊勢貞夫：ラジオゾンデ用気球の放球に関する一考 察，研究時報29巻，札幌管区気象台，1977年.

19）角俊治：気球の上昇速度について, 高層気象台彙報, 第 6 巻, 第 2 号.

20）今井一郎：気球の上昇速度について, 気象集誌, Vol.32，1957年.

21）気象庁：高層気象観測指針，1973年.

22）相馬清二：富士山風下の乱気流，富士山

23）早川満ほか：光化学オキシダント高濃度污染日の流跡 線解析，東京都公害研究所年報，1982年. 